\title{
BEHAVIOUR OF STRIP FOOTING SUPPORTED ON GEOTEXTILE REINFORCED SOIL UNDER REPEATED LOADING
}

\author{
Snehal U. Malpani \\ Civil Department, \\ Government College of Engineering, \\ Aurangabad, Maharashtra, India
}

\begin{abstract}
This paper presents the results of laboratory model tests performed on strip footings supported on unreinforced and geotextile-reinforced sand bed under a combination of static and repeated loads. Footing settlement due to initial static applied load was recorded, until its value become stable or failure occurred due to excessive settlement. The response under the first few cycles was found to be a significant behavioural characteristic of footings under repeated loads. The influence of various amplitudes of repeated load on foundation and different numbers of geotextile layers below the footing base on dynamic behaviour of footing were investigated. Footing settlement patterns due to repeated loading of reinforced soil is found to be comparable with increases in the numbers of geotextile layers reducing the magnitude of the final settlement and usually acting as a settlement retardant against the effects of repeated loading. The reinforcement's efficiency in reducing the maximum footing settlement decreased as numbers of geotextile layers was increased.
\end{abstract}

Keywords - Repeated loads; Strip footing; settlement; Geotextile reinforcement.

\section{INTRODUCTION}

Research into the behaviour of soil and shallow foundations subjected to static loads was initiated during the 1960s. Both theoretical and experimental studies of the static bearing capacity of shallow foundations on unreinforced soil have been reported by researchers. Experimental observations of the load-settlement relationships of square surface foundations supported by sand and clay and subjected to transient loads were reported by Cunny and Sloan (1961), Jackson and Halada (1964), Raymond and Komos (1978) and Das and Shin (1996). In recent decades, due to its economy, ease of construction and ability to improve the visual appearance, reinforced soil has been widely exploited in geotechnical engineering applications such as the construction of roads, railway embankments, stabilization of slopes, and improvement of soft ground and so on. In the case of reinforced footings under dynamic loads, only a few relevant

\author{
Prof. G. K. Patil \\ Civil Department, \\ Government College of Engineering, \\ Aurangabad, Maharashtra, India
}

studies have been found and these concentrated on planar reinforced applications (Das, 1998; Das and Shin, 1994; Raymond, 2002). Shin et al. (2002) investigated the possibility of using geogrid layers as reinforcement to reduce the settlement of a railroad bed and sub-ballast layer subjected to cyclic load. They reported that the most beneficial effect of reinforcement is derived when one layer of geogrid is placed at the interface of the subgrade soil and the sub-ballast course. Also, Moghaddas Tafreshi and Khalaj (2008) performed an experimental study to investigate the behaviour of pipes buried in geogrid reinforced sand when subjected to repeated loads. They reported that the use of geogrid reinforcement can significantly reduce the vertical diameter change of pipe and settlement of the soil surface.

In the current research described here, and in order to develop a better understanding of the behaviour of footings under a combination of static and repeated loads supported on geotextile-reinforced soil beds, a series of different laboratory, pilot-scale tests were performed. In these tests the settlement of a strip footing supported by reinforced relatively dense soil with geotextile reinforcement is evaluated. The overall goal was to investigate the response of footings above reinforced sand and unreinforced sand to repeated loading, the effects of the number of geotextile layers below the footing base and the ratio of repeated load intensity to applied static load. It should be noted that only one type of geotextile, one footing width, and one type of soil were used in laboratory tests. It is recognized that the results of this study may be somewhat different to full-scale foundation behaviour in the field, although the general trend is expected to be similar.

\section{Testing APPARATUSES And Test Procedure}

The testing tank is designed as a rigid box (as the plane strain conditions were achieved), $750 \mathrm{~mm}$ in length, $500 \mathrm{~mm}$ in height, and $200 \mathrm{~mm}$ in width, encompassing the reinforced soil and model foundation (see Figure 1). To prepare the test and in order to provide experimental control and repeatability of the tests, the raining technique (Kolbsuzewski, 1948) was used to deposit the soil in the testing tank to consistently maintain a relative density of $72 \%$. In the case of the reinforced bed, by considering the position of the reinforcement layers, the inner 


\section{International Journal of Engineering Applied Sciences and Technology, 2019 Vol. 4, Issue 2, ISSN No. 2455-2143, Pages 77-81 \\ Published Online June 2019 in IJEAST (http://www.ijeast.com)}

face of the tank was marked beneath the position of footing to facilitate accurate preparation of the reinforced sand bed. The soil was rained from the prescribed height through the perforated plate in the tank and then on reaching the first reinforcement level, raining of soil was temporarily ceased. Thereafter the first geotextile layer was placed on the surface of the soil, after which the soil raining was continued until the desired level of the second geotextile layer was achieved. The preparation of the reinforced sand bed used one to four planar geotextile layers. After final geotextile placing, soil raining was continued up to the footing level. The model footing used was made of a steel rigid plate and measured, $140 \mathrm{~mm}$ in length, $100 \mathrm{~mm}$ in width and $20 \mathrm{~mm}$ in thickness. The setting of machine is prepared in such a way so that both load and settlement could be read and recorded automatically.

The initial static load, $\mathrm{q}_{\mathrm{stat}}$ was applied at a rate of $1.0 \mathrm{kPa}$ per second. The repeated load having amplitude of $\mathrm{q}_{\mathrm{dyn}}$ is superimposed on the static load. Before applying the repeated load, the static load (see Figure 1) is kept constant until no further settlement occurs or the rate of settlement becomes negligible. During the tests the static load would permanently apply on the footing while the repeated load was returned to zero at the end of each cycle. Sinusoidal load cycles with a frequency of $1 \mathrm{~Hz}(1 \mathrm{cycle} / \mathrm{sec})$ would be continued until the rate of change of total settlement drops to an insignificant amount or, alternatively, excessive settlement and unstable behavior is observed.

\section{A. Material Used}

The soil used is black cotton soil and with a specific gravity, Gs, of 2.68. It has a Coefficient of uniformity, $\mathrm{Cu}$, of 1.35 , Coefficient of curvature, $\mathrm{Cc}$, of 0.95 , Effective grain size, D10, of $1.2 \mathrm{~mm}$, Medium grain size, D50, of 1.53. The maximum and minimum void ratio $\left(\mathrm{e}_{\max }\right.$ and $\left.\mathrm{e}_{\min }\right)$ of the soil were obtained as 0.82 and 0.54 , respectively.

The type of geotextile used, is non-woven. The engineering properties of this geotextile as listed by manufacturer (DuPont de Nemours, Luxembourg) are: thickness $0.57 \mathrm{~mm}$, mass per unit area $190 \mathrm{gr} / \mathrm{m} 2$, ultimate tensile strength $13.1 \mathrm{kN} / \mathrm{m}$ and effective opening size $0.08 \mathrm{~mm}$.

\section{B. Test Parameters And Testing Program}

The geometry of the test configurations considered in these investigations is shown in Figure 1. Also, the details of the tests are given in Table 1. The depth of first reinforcement layer from the base of the footing $(\mathrm{u} / \mathrm{B})$, the vertical layer spacing $(\mathrm{h} / \mathrm{B})$, and the values of lateral extents of the geotextiles $(\mathrm{b} / \mathrm{B})$ were selected based on preliminary tests not reported here (Moghaddas Tafreshi and Dawson, 2010), respectively $0.35,0.35$ and 4.1 . Tests series 1 was carried out on unreinforced bed to quantify the improvements due to reinforcements and Tests series 2 were carried out on reinforced sand bed to study the effect of the number of reinforced layers $(\mathrm{N})$ and intensity of repeated load (qdyn/qstat) at optimum values of $\mathrm{u} / \mathrm{B}, \mathrm{h} / \mathrm{B}$ and $\mathrm{b} / \mathrm{B}$.

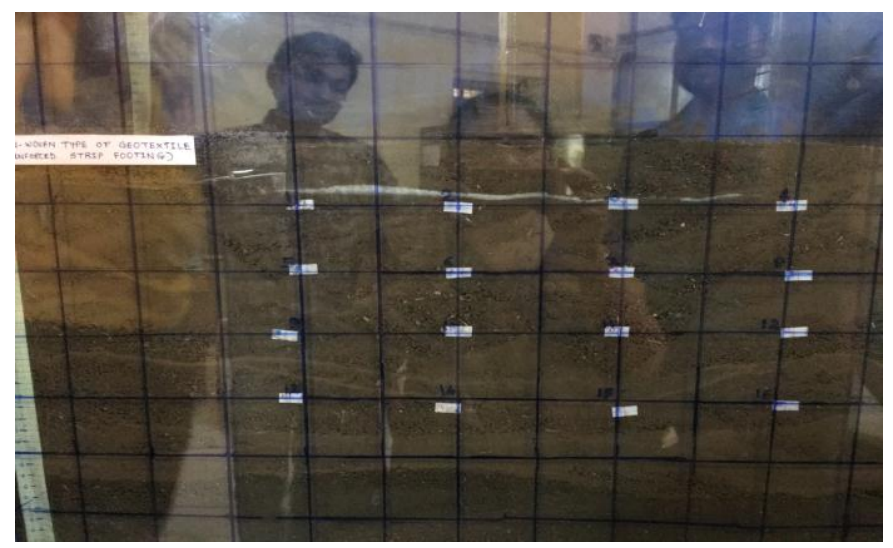

Fig 1. Geometry of the planar geotextile-reinforced foundation bed.

Some of the tests described in Table 1 were repeated carefully at least twice to examine the performance of the apparatus, the accuracy of the measurements, the repeatability of the system, reliability of the results and finally to verify the consistency of the test data.

Table1. Scheme of the repeated load tests for unreinforced and geotextile reinforced soil

\begin{tabular}{|c|c|c|c|c|}
\hline $\begin{array}{c}\text { Test } \\
\text { Series }\end{array}$ & $\begin{array}{c}\text { Type Of } \\
\text { Reinforcement }\end{array}$ & Load & N & $\begin{array}{c}\text { No. Of } \\
\text { Tests }\end{array}$ \\
\hline 1 & Unreinforced & $3.5 \mathrm{kN}$ & ----- & 5 \\
\hline 2 & Reinforced & $3.5 \mathrm{kN}$ & $1,2,3$ & $5 * 3$ \\
\hline
\end{tabular}

The results obtained depicted a close match between results of the two or three trial tests with maximum differences in results of around $10 \%$.

\section{EXPERIMENT AND RESULT}

In this section, the tests results of the laboratory model are presented with a discussion highlighting the effects of the different parameters. The presentation of all the result figures would have made the paper lengthy, so only a selection is presented.

\section{A. The effect of the amplitude of the repeated load}

The variation of the maximum footing settlement to footing width, s/B, with number of applied load repetitions as a consequence of the repeated loading pattern is plotted in Figure 2. The data are presented for unreinforced and reinforced sand beds. Also the final footing settlement of all tests (proportional to footing width), s/B, on the unreinforced and reinforced beds for different amplitude of repeated load is shown in Table 2. From this table, in the cases of the unreinforced sand beds under cyclic loads and in the case of the sand bed reinforced with one geotextile layer under strong cyclic loads with static load, excessive settlement and consequently unstable behaviour is observed .The values of 
footing settlement for these three tests which exhibit rupture are shown in Table 2. Therefore the values of footing settlement for these three tests in Table 2 which exhibit rupture are only used to clarify the role of the soil reinforcement.

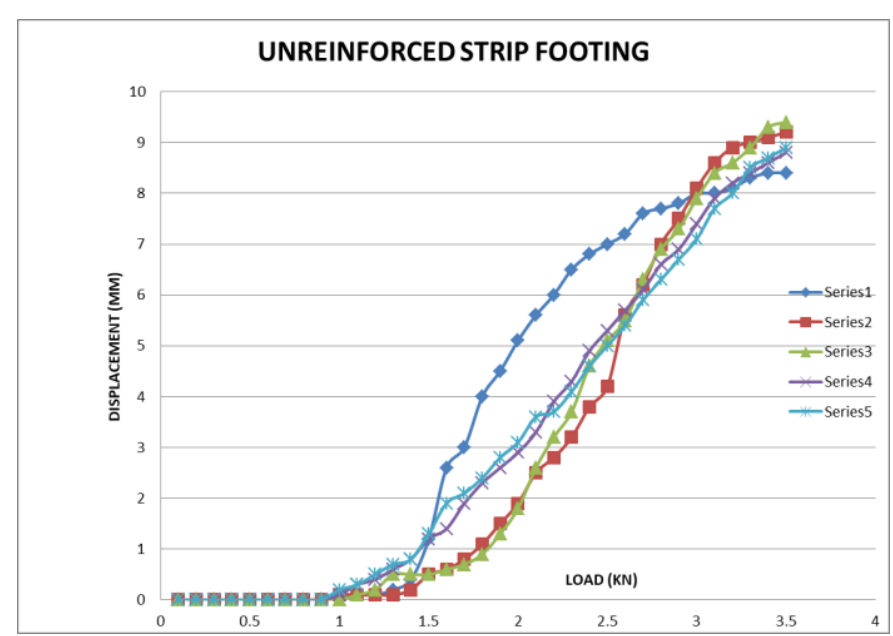

Fig 2. Variation of the footing settlement (s/B) with number of applied load repetitions for the unreinforced beds.

Based on the Figure 2 and Table 2, it can be found that using the reinforcement with the number of layers greater than 1, leads to stabilising behaviour, irrespective of the repeated load level, qdyn/qstat, whereas no-reinforcement or under-reinforcement allows excessive settlement and unstable behaviour to develop. Also, in the case of the unreinforced sand beds under repeated loading, it is apparent that the excessive settlement commenced.

Table 2: Summary of shakedown settlement results obtained under repeated loading, s/B (\%)

\begin{tabular}{|c|c|c|c|c|}
\hline $\begin{array}{c}\text { Load } \\
(\mathrm{kN})\end{array}$ & \multicolumn{3}{|c|}{ Reinforced soil } & $\begin{array}{c}\text { Unreinforced } \\
\text { soil }\end{array}$ \\
\hline & $\mathrm{N}=1$ & $\mathrm{~N}=2$ & $\mathrm{~N}=3$ & \\
\hline 3.5 & 7.8 & 5 & 2.94 & 8.94 \\
\hline
\end{tabular}

It is interesting to note that in the most of the tests performed on the reinforced soil bed, the initial rapid settlement that took place during the first 10-20 cycles of loading gave rise to about $35 \%$ to $60 \%$ of the total settlement, the actual proportion depending on the mass of reinforcement and on the magnitude of the applied repeated load.

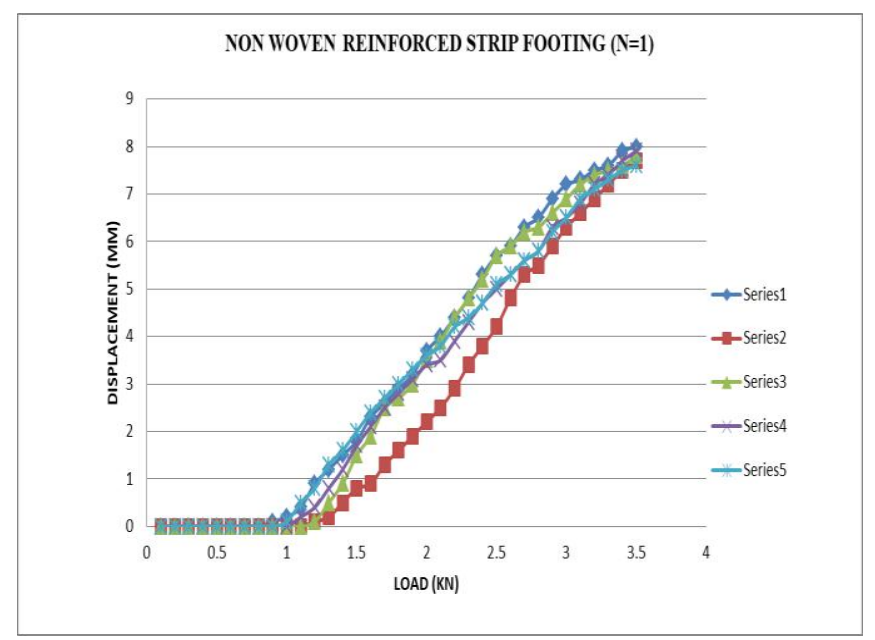

Fig 3. Variation of the footing settlement (s/B) with number of applied load repetitions for the reinforced beds $(\mathrm{N}=1)$.

Figure 3 shows the variation of the maximum footing settlement ( $\mathrm{s} / \mathrm{B})$ with amplitude of repeated loads for the reinforced and unreinforced beds. From this figure it can be observed that, although there is some scatter, the footing settlement varies linearly with qdyn/qstat. As expected, the increase in the magnitude of the repeated loads directly causes the footing settlement to increase for both unreinforced and reinforced sand beds.

\section{B. The effect of the number of layers of the reinforcement}

Figure 4 summarizes the variation in the maximum footing settlement with number of applied load repetitions for the three reinforced cases $(\mathrm{N}=1,2,4)$ and for the unreinforced sand bed. It can be noted that the variation rate of peak footing settlement reduces as the number of cycles increase, and finally becomes stable after a certain number cycles, irrespective of the number of layers of planar reinforcement $(\mathrm{N})$. On the other hand, the magnitude of footing settlement increases with number of cycles (n) and reaches a sensibly constant maximum value at the number of load cycles. 


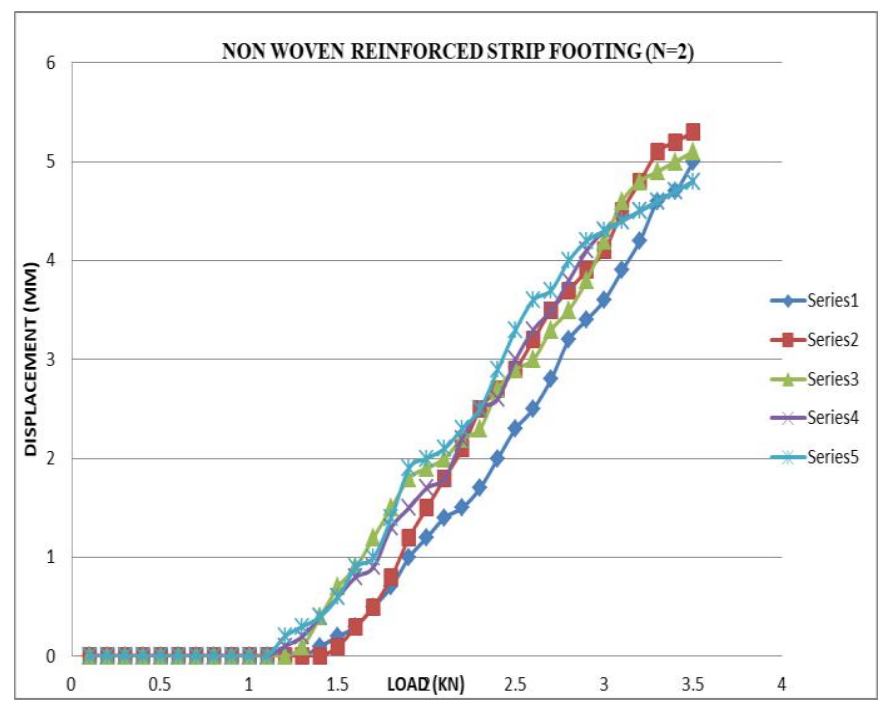

Fig 4. Variation of the footing settlement (s/B) with number of applied load repetitions for the reinforced beds $(\mathrm{N}=2)$.

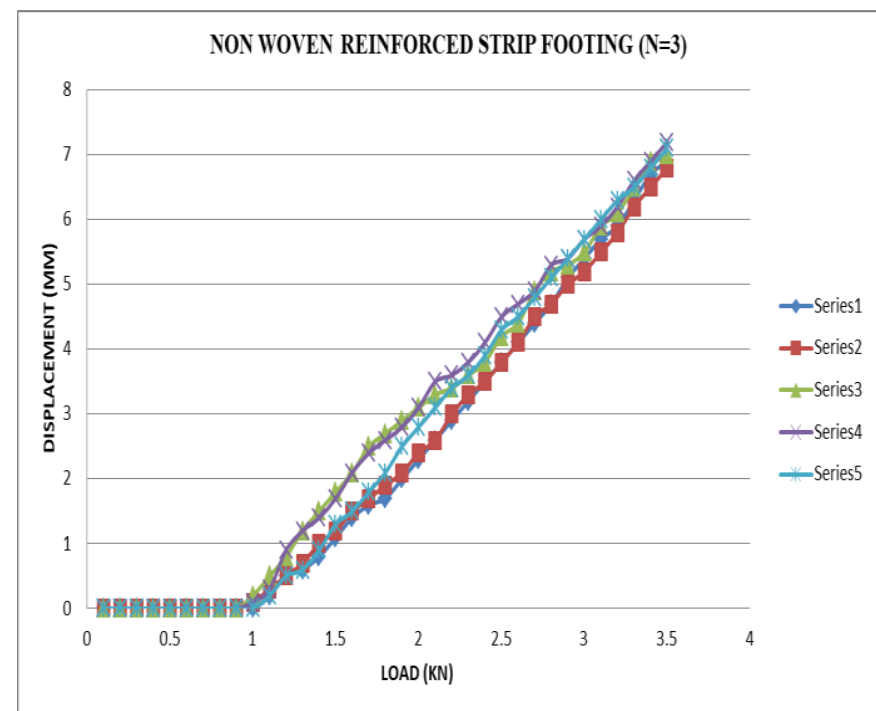

Fig 5. Variation of the footing settlement $(\mathrm{s} / \mathrm{B})$ with number of applied load repetitions for the reinforced beds $(\mathrm{N}=3)$.

\section{CONCLUSION}

Based on the results obtained from the present study, the following conclusions can be drawn:

(1) The rate of footing settlement decreases significantly as the number of loading cycles increases. The largest portion of the footing settlement after the first 10-20 cycles varies between 0.35 and 0.6 of footing width.

(2) The magnitude of the maximum footing settlement and the number of cycles required to be stabled of the footing settlement are a function of the initial applied static load (qstat), the amplitude of the repeated load (qdyn) and the mass of reinforcement below the footing base $(\mathrm{N})$.
(3) For a given value of amplitude of repeated load, with increase in the number of reinforcement layers, the footing settlement decreases while the efficiency of reinforcement was decreased by increasing the mass of reinforcement.

(4) With increase in the amplitude of repeated load, the value of footing settlement increases, irrespective of the number of reinforcement layers.

Although, the results of this research are obtained for only one type of geotextile, one size of footing width, and one type of soil based on the tests conducted on a small model strip footing in plane strain conditions, however these results will be helpful in designing large-scale model tests, for simulation studies using numerical models and in the application of the concepts at full-scale.

\section{REFERENCE}

[1] Cunny, R.W. et al.(1961). Dynamic loading machine and results of preliminary small scale footing tests. ASTM Special Technical Publication 305, 65-77.

[2] Das, B.M. et al.(1996). Laboratory model tests for cyclic load-induced settlement of a strip foundation on clayey soil. Geotechnical and Geological Engineering 14:3, 213 225.

[3] Das, B.M. (1998). Dynamic Loading on Foundation on Reinforced Sand. Geosynthetics in Foundation Reinforcement and Erosion Control Systems, ASCE 76, 19-33.

[4] Shin, E.C.et al. (1994). Strip foundation on geogridreinforced clay: Behaviour under cyclic loading. Geotextiles and Geomembranes 13:10, 657-667.

[5] Jackson, J.G. et al.(1964). Dynamic bearing capacity of soils, Report 3: The Application of Similitude to SmallScale Footing Tests, US Army Crops of Engineers, Waterways Experiment Station, Vicksburg, MS.

[6] Kolbsuzewski, J. (1948). General investigation of the fundamental factors controlling loose packing of sands. Proc. of the 2nd Int. Conf. on Soil Mech. And Found. Eng., Rotterdam VII, 47-49.

[7] Khalaj, O.et al. (2008). Laboratory tests of small-diameter HDPE pipes buried in reinforced sand under repeated load. Geotextiles and Geomembranes 26:8, 145-163.

[8] Moghaddas Tafreshi,et al.(2010). Comparison of bearing capacity of a strip footing on sand with geocell and with planar forms of geotextile reinforcement. Geotextiles and Geomembranes 28:1, 72-84.

[9] Raymond, G.P., et al. (1978). Repeated load testing on a model plane strain footing. Canadian Geotechnical Journal 15:2, 190-201. 
[10] Raymond, G.P. (2002). Reinforced ballast behaviour subjected to repeated load. Geotextiles and Geomembranes 20:1, 39-61.

[11] Shin, E.C. et al. (2002). Bearing capacity of strip foundation on geogrid reinforced sand. Geotechnical and Geological Engineering 20, 169-180.

[12] Shields D H, et al.(1977) Barsvary Y. Bearing capacity of foundation near slopes [C]// Proceedings of the 9th International Conference on Soil Mechanics and Foundation Engineering. Tokyo, 2: 715-720.

[13] Hansen B. A. (1970) revised and extended formula for bearing capacity [R]. Copenhagen: Danish Geotechnical Institute Bui, 28: 5-11.

[14] Vesic A S. (1973) Analysis of ultimate loads of shallow foundations [J]. JSMFD, ASCE, 99(SMI): 45-73.

[15] Bowles J.(1996) Foundation analysis and design, 5th Ed. [M]. New York: McGraw-Hill.

[16] Castelli F, et al (2010) Bearing capacity of strip footings near slopes [J]. Journal of Geotechnical and Geological Engineering, 28(2): 187-198.

[17] Kumar A, et al(2007) . Bearing capacity tests of strip footings on reinforced layered soil [J]. Journal of Geotechnical and Geological Engineering, 25(2): 139150. 